\title{
Formulation and Characterization of Adhesive Produced From Polystyrene Waste Using Response Surface Optimization
}

\author{
Lucas Albert Jerome Hamidu ${ }^{1}$, Umar Omeiza Aroke ${ }^{2}$, Odeh Adey Osha ${ }^{2}$, \\ Idris Misau Muhammad ${ }^{2}$
}

${ }^{1}$ Nigerian Building and Road Research Institute

10, NBRRI Way/ I.T. Igbani Street, off Awolowo Way, Jabi, Abuja, Nigeria

${ }^{2}$ Abubakar Tafawa Balewa University

Dass road, P. M. B. 0248, Bauchi, 740272, Nigeria

DOI: $10.22178 /$ pos. $49-2$

LCC Subject Category: QD1-65

Received 06.07.2019

Accepted 28.08.2019

Published online 31.08.2019

Corresponding Author:

Lucas Albert Jerome Hamidu

lucadohamidu@yahoo.com

(C) 2019 The Authors. This article

is licensed under a Creative

Commons Attribution 4.0 License

(c) (1)

\begin{abstract}
Polystyrene is extensively used in building and construction industry, packaging and transportation of fragile equipment due its low density, high melting point, low thermal conductivity, low water absorption, etc. Polystyrene after usage is usually discarded thereby causing environmental problems. The post-usage of polystyrene has, therefore, been a subject of intense research in recent times. The aim of this work is to produce adhesive from polystyrene wastes. Polystyrene waste (PS) was collected, processed and dissolved in tackifyer and formulated with diphnyle amine and diethylene glycol dibenzoate additives to produce adhesive using 3 levels variables factors and 4 levels testing factors of design expert optimization software. The produced adhesive was further characterized for viscosity, $\mathrm{pH}$, percentages solid and moisture contents for their response surfaces. The results showed that the best fit viscosity for each run was Run $1 B>$ Run $5 A>$ Run $5 D>$ Run $5 B>$ Run $4 D$ based on the regression analysis and analysis of variance (ANOVA). The $\mathrm{pH}$ values obtained ranged from 4.0 to 6.3; percentage moisture content was in the order of Run $1 B<5 A<4 D<4 B$ and percentage solid content was in the order of Run $1 B<5 A<4 D$. The best fitted adhesive was run $1 B$ with $5.93 \%$ moisture content; $5 \mathrm{~A}$ has $7.57 \%$ moisture content and $4 \mathrm{D}$ with $8.76 \%$ moisture content. The percentage solid content; Run 1B has $67.19 \%, 5 \mathrm{~A}$ has $68.16 \%$ and 4D has $75.50 \%$. The produced adhesives were found within the standard range of adhesives used in production of particleboard.
\end{abstract}

Keywords: adhesive; characterization; formulation; polystyrene waste; response.

\section{INTRODUCTION}

Waste is any unavoidable material resulting from domestic, industrial or social operations that are not having any economic value and the end results is disposal. The prevailing situation of indiscriminate disposal of non-biodegradable waste materials is a great concern for sustainable ecosystem and clean environment. Nevertheless, these wastes could also contain a lot of valuable resources in the form of nitrogen, phosphorus, potassium, methane and other chemicals which might be useful [1]. The search for better life and socio-economic activities contributes to generation of these wastes from different sources, which are either classified as solid or liquid [2].

Polystyrene which is known as Styrofoam is a synthetic aromatic polymer made from monomer of styrene, which can either be solid or foamed. It is traditionally produced by alkylation of benzene reacting with ethylene to produce ethylbenzyene. Its dehydration results into formation of styrene monomer [3]. The Chemical formula is $\left[-\mathrm{CH}_{2}-\mathrm{CH}-\left(\mathrm{C}_{6} \mathrm{H}_{5}\right)-\right] n$ and has molecular weight of $104.15 \mathrm{~g}$ [4].

Polystyrene decomposes between the temperature ranges of 350 to $450{ }^{\circ} \mathrm{C}[5,6]$. Take as much as $30 \%$ of landfills worldwide [7] and has low density $[3,8]$. Highly flammable, releases lots of black smoke when combusted and generally nonbiodegradable [9]. Recycling is not economical [10]. Incineration requires high temperatures up to $1000^{\circ} \mathrm{C}$ and plenty air, as much as $14 \mathrm{~m}^{3} / \mathrm{kg}$ [11]. When buried remain as nondecayed materials, preventing water infiltration to the ground [12]. However; it dissolves easily in chlorinated solvents and many other aromatic 
hydrocarbons $[7,13,14]$. This research is aimed at conversion of polystyrene waste to adhesive using affordable solvents and additives for stabilization. This will also be of more economic value and create clean and sustainable environment.

Adhesive is a substance when applied to substrates sticks to the surfaces that two become bonded together by wetting the surfaces to be joined [15]. It is either natural from animal bone and vegetable sources or synthetic from chemicals [16] depending on the source of formulation. Researchers have shown that adhesives are used in furniture making [17] and composite materials such particleboard for modern furniture for both industrial, domestic and office usage [12, 18]. However, $80 \%$ of adhesive used in productions of wood based panels contains urea formaldehyde [19], has been reported carcinogenic and non-friendly to the users [20, 21, 22]. Various formulations have been experimented to reduce its emission to cushion its health effect are still at the infant stage. Considering the health effects of urea formaldehyde resin in production of composite materials, this research is desired to formulate adhesive from polystyrene waste for particleboard production.

C. Xing [23] determined the effect of $\mathrm{pH}$, solid and catalyst on the gel time of urea formaldehyde adhesive. The following factors determines adhesive quality; viscosity, $\mathrm{pH}, \%$ M. C. \& \% TS as used in most composite materials and panel production $[24,25,26,27,28]$.

Adhesive $\mathrm{pH}$ is critical in ascertaining its longevity and handling processes [29, 30, 31]. It's determined the applicability of adhesive as curing depends of $\mathrm{pH}$ value. The percentage moisture (\% M. C.) of adhesive determines the longevity and its adherends to substrates during application, and for non-water soluble adhesive it should be less than $10 \%[13,32,33]$. Authors [34] and [19] reported that high moisture contents dilute the adhesive which could weaken its strength in adhesion to substrates. The procedure for determination of adhesive \% M. C. is by using Equation 1 [32].

$$
\begin{aligned}
& \text { Moisture content, } \%= \\
& =\frac{\text { Original weight }- \text { Dry weight }}{\text { Original weight }} \times 100
\end{aligned}
$$

The solid content (\%TS) is critical in quality parameters of adhesive, for water soluble the solid content is within the range of $55-57 \%$ [19], while non-water soluble are greater than $65 \%$ $[24,27]$. The procedure for determination of $\%$ TS is by using Equation 2 [35].

$$
\text { Solid content, } \%=\frac{\text { Dry weight }}{\text { Original weight }} \times 100 \text {, }
$$

In this research, design expert 6.0.8 version software was used in the formulation of adhesive [15]. The resin was formulated using polystyrene waste and tackifyer at different ratios, and followed by 3 factor development of adhesive with additives [36]. The produced adhesive was further characterized with 4 response surfaces.

\section{MATERIALS AND METHODS}

Polystyrene waste was collected from commercial outlets in Bauchi metropolis, the tackifyer was obtained from Total Filling station, Yelwa. The reagents used: diphenyl amine (99.9\% purity), diethylene glycol dibenzoate (99.8\% purity) BDH Chemical and absolute ethanol (98$99 \%$ purity) Nertherlands GPR were purchased from a local vendor. The equipment used were digital weighing balance model PGW 45021, Hot Air Oven, Rotary viscometer model TT-5, pH meter model JENWAY 3510, mechanical stirrer model Heidolph 50111 and measuring cylinders.

Polystyrene wastes were first washed and dried, then fragmented and weighed. The plasticizer was synthesized from diethylene glycol and benzoic acid, tackifyer and antioxidant were formulated based on experimental design. This was followed by formulation of resin based on 2 factorial design using mixture following the procedure as presented in Equation 3 [15, 24].

$$
\begin{aligned}
& \text { Polystyrene waste (PS), g+ } \\
& + \text { Tackifyer }(T k f), g=1
\end{aligned}
$$

Resin design formulation is presented in Table 1.

Table 1 - Resin Design Formulation

\begin{tabular}{|c|c|c|c|c|c|}
\hline \multirow{2}{*}{$\begin{array}{c}\text { Component, } \\
\text { g }\end{array}$} & \multirow{2}{*}{$\begin{array}{c}\text { Low } \\
\text { limits }\end{array}$} & Constraints & \multirow{2}{*}{$\begin{array}{c}\text { High } \\
\text { limits }\end{array}$} & \multicolumn{2}{|c|}{$\begin{array}{c}\text { Coded } \\
\text { factors }\end{array}$} \\
\cline { 4 - 6 } & & & Low & High \\
\hline PS & 0.50 & A & 0.75 & 0 & 1.000 \\
\hline Tkf & 0.25 & B & 0.50 & 0 & 1.000 \\
\hline
\end{tabular}


After resin formulation, 3 factorial designs variables were developed to produce adhesive using mixture design expert and D-optimal for response surfaces. Equation 4 presents the formulation procedure for adhesive formulation [15, 36].

$$
A+B+C=1,
$$

Adhesive experimental design is presented in Table 2.

Table 2 - Design Constraints Table Adhesive formulation using D-optimal

\begin{tabular}{|l|l|l|c|c|c|c|}
\hline \multirow{3}{*}{ Component } & \multirow{2}{*}{ Name } & \multirow{2}{*}{ Units } & \multicolumn{2}{|c|}{$\begin{array}{c}\text { Actual } \\
\text { values }\end{array}$} & \multicolumn{2}{c|}{$\begin{array}{c}\text { Coded } \\
\text { Values }\end{array}$} \\
\cline { 4 - 8 } & & & Low & High & Low & High \\
\hline $\mathrm{A}$ & Resin & $\mathrm{g}$ & 0.65 & 0.79 & 0.000 & 0.993 \\
\hline $\mathrm{B}$ & Plasticizer & $\mathrm{g}$ & 0.20 & 0.34 & 0.000 & 1.000 \\
\hline $\mathrm{C}$ & Antioxidant & $\mathrm{g}$ & 0.009 & 0.01 & 0.000 & 0.007 \\
\hline
\end{tabular}

The produced resin was further blended with PLZ and AOX based on the DOE ratios and stirred with the addition of additives at ambient conditions, resulting into a thin film of adhesive produced. The produced adhesives were characterized for their response surfaces results at ambient conditions.

Rotary viscometer model TT- 5 was used according to the standard procedure [37]. The apparatus were set on automatic mode, with the selection of appropriate spindle for viscosity test. It was gribbed, adjusted and inserted into the adhesive up to a mark. The automatic rotary viscometer was powered on to start running as it selects the rotation in revolution per minute (RPM) at 6, 12, 30 and 60. After every rotation it displays the data for the viscosity at each RPM which was recorded as the viscosity at that point. This test was rerun three (3) times for each sample for accuracy.

The $\mathrm{pH}$ meter JENWAY model was used to determine the $\mathrm{pH}$ of the produced adhesive before and after stirring. The meter was cleansed with solvent to be free of dirt and impurities on the electrodes. It was followed by stabilization in buffer solution and immersion in the sample. The meter start reading immediately when it is immersed until it attains stability and a curve is displayed with ready showing optimal value plotted. The test was rerun three (3) times for each sample for accuracy.
The percentage solid content of produced adhesive was determined using laboratory crucibles. A known quantity of the sample was weighed and oven dried at a temperature of $200 \mathrm{oC}$. After 2 hours, the sample drying was discontinued and removed from the oven to cool and weighed after as dry weight.

\section{RESULTS AND DISCUSSION}

The viscosities of produced adhesives were determined and their results are presented in Figures 1-3.

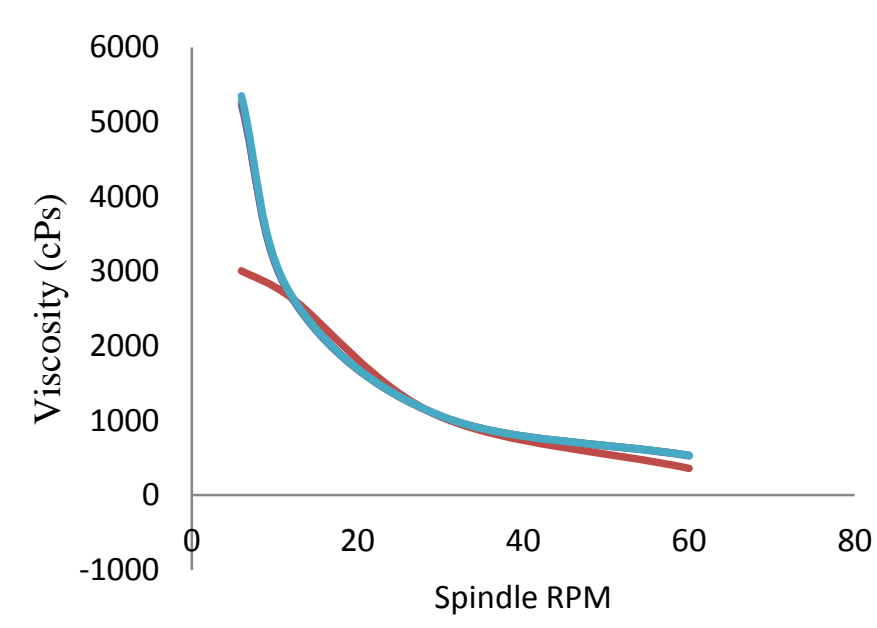

Figure 1- Run 1 Viscosities

Figure 1 present viscosity curves for run 1 of produced adhesives 1 (A, B, C, D \& E) in triplicates, some curves were overlapping due to closer values of the viscosities. The values obtained are: Runs 1A, 5267 cPs; 1B, 3006 cPs; 1C, 5285 cPs; 1D, 5228 cPs \& 1E, 5351 cPs. These values were found within the range of viscosity data for urea formaldehyde adhesive used in particle board [25, 26, 27]. The data was modeled to get the best fit using regression $\left(\mathrm{R}^{2}\right)$ curve and DOE response model [24]. The results showed that $\left(\mathrm{R}^{2}\right)$ are: Runs; $1 \mathrm{~A} 0.7034 ; 1 \mathrm{~B} 0.9105 ; 1 \mathrm{C}$ 0.7042; 1D 0.7077 \& 1E 0.7010. Run 1B $\left(R^{2}\right)$ and 0.8612 . Thus; run $1 \mathrm{~B}$ is considered significant model which can be used to navigate the design.

Figure 2 presents viscosity curve for Run 4 (A, B, C, D \& E) in triplicates. The viscosity data obtained are: 4A, $5240 \mathrm{cPs} ; 4 \mathrm{~B}, 5259 \mathrm{cPs} ; 4 \mathrm{C}, 5250$ cPs; 4D, 4846 cPs \& 4 E, 5229 cPs. Furthermore, the $\mathrm{R}^{2}$ values are: $4 \mathrm{~A}, 0.7035 ; 4 \mathrm{~B}, 0.7039 ; 4 \mathrm{C}$, $0.6468 ; 4 \mathrm{D}, 0.7265 \& 4 \mathrm{E}, 0.7048$ respectively. 


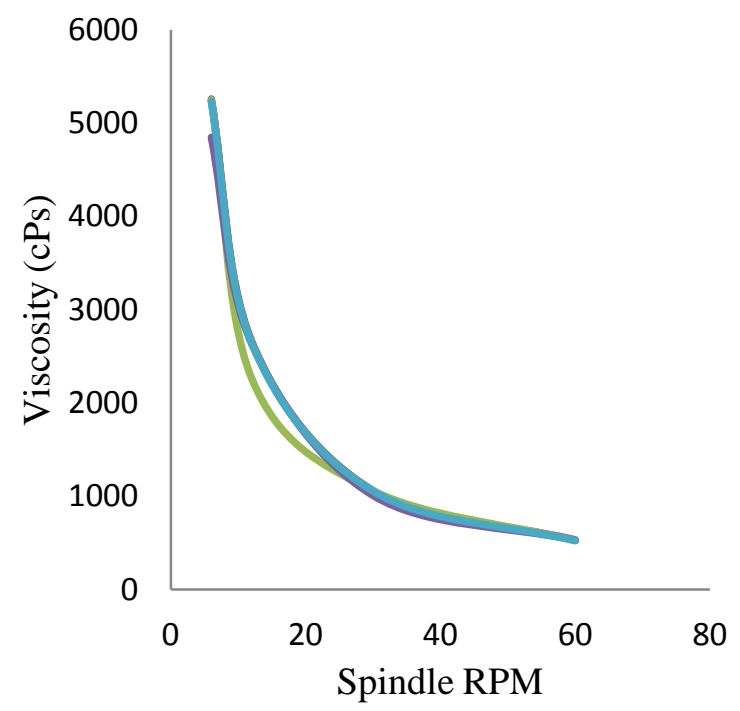

Figure 2 - Run 4 Viscosities

Viscosities obtained in this experiment falls within the range of viscosity of urea formaldehyde used as binder in panel and other composites materials production [25, 26, 27].

Figure 3 presents viscosity curve for Run 5(A, B, C, D \& E) in triplicates. The viscosities data obtained are: 5A, 2431 cPs; 5B, 1925 cPs; Runs 5C, $5 \mathrm{D} \& 5 \mathrm{E}$ data were not detected by the viscometer which implies lack of adhesive fitness. Furthermore, the $\mathrm{R}^{2}$ values are; $5 \mathrm{~A}, 0.8201 ; 5 \mathrm{~B}$, $0.7808 ; 5 C, 5 \mathrm{D}, 0.8148 \& 5 \mathrm{E}, 0.6602$ respectively.

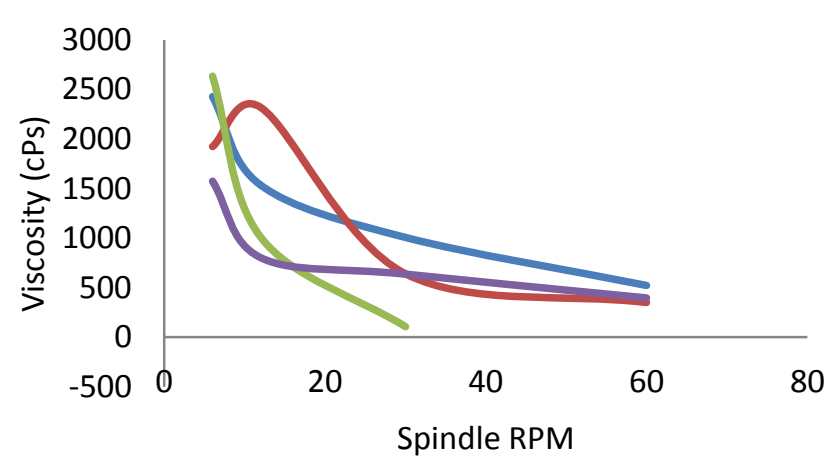

Figure 3 - Run 5 Viscosities

Even though these viscosities values falls within the range of viscosity of urea formaldehyde used as binder in panel and other composites materials production [25, 26, 27, 37], the RS model fails to recommend this model for navigation. Thus; the overall viscosities result analysis revealed that Run $1 \mathrm{~B}$ model values shows significant model that could be used to navigate the design having $\mathrm{R}^{2}$ value of 0.9105 .

Figures 4-6 presents the pH values obtained from adhesives developed. The response surfaces were determined before and after stirring to study the effect of stirring on acidity content.

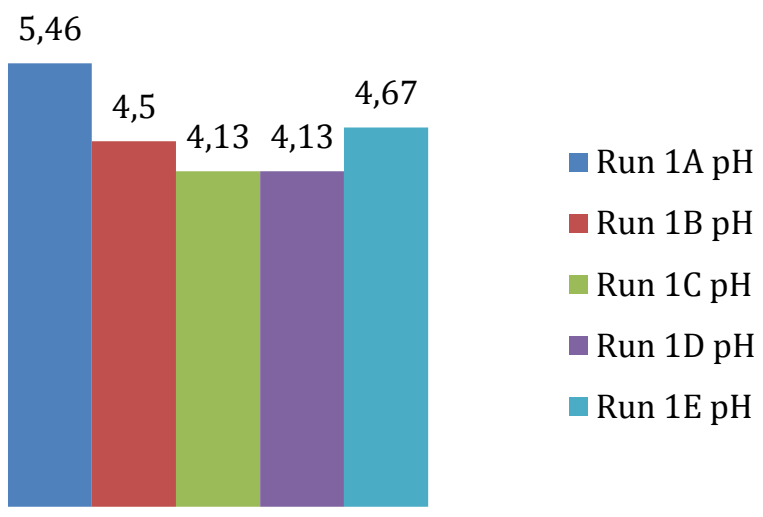

Figure 4 - Run 1 pH before and after Stirring

Figure 4 presents results of $\mathrm{pH}$ data obtained from experimental results before and after stirring. The $\mathrm{pH}$ before stirring was lower than the $\mathrm{pH}$ after stirring; this differential could be due to the effect of homogenization of the sample after stirring with phase disappearing after stirring. It also suggests the presence of plasticizer ratio in the produced adhesive. The values obtained were within the reported values of urea formaldehyde resin used in particleboard production [27]. However; this acidity was as result of dibenzoate used in plasticizer and is a weak acid with less effect on the cure rate of the produced adhesive.

Figure 5 presents the pH values of experimental data results for runs 4 before and after stirring. 


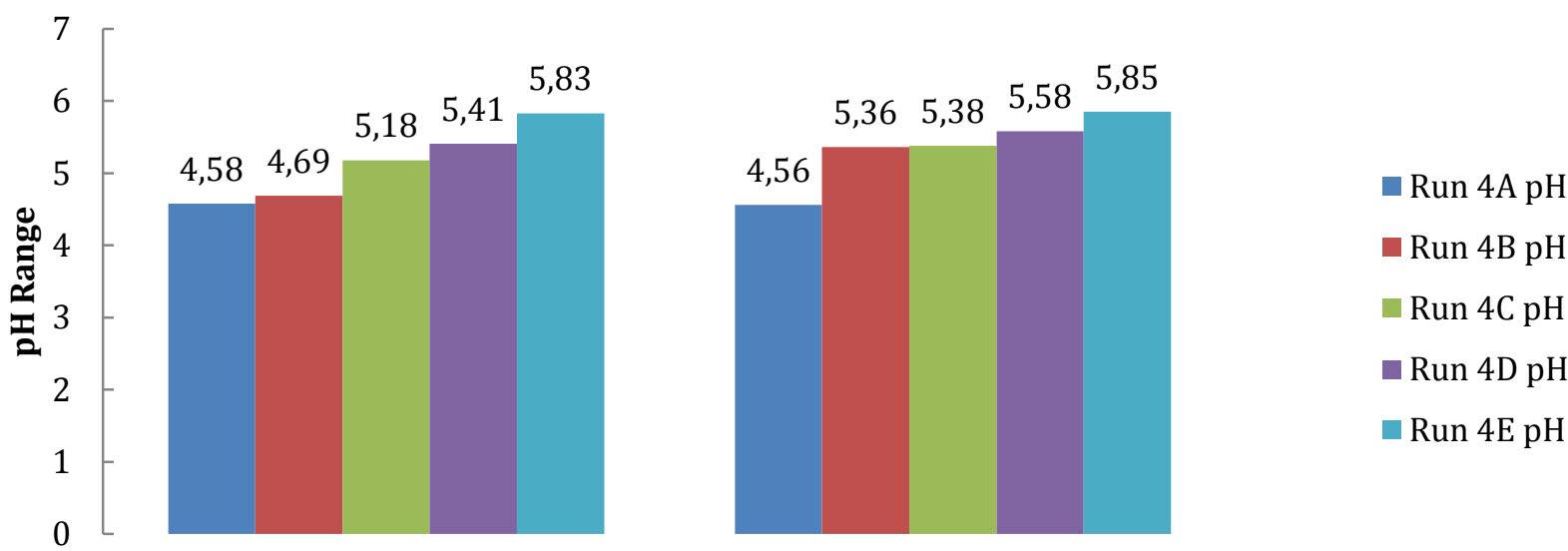

Figure 5 - Run $4 \mathrm{pH}$ before and after Stirring

Except for run 4A, which shows drop in pH after stirring, the remaining had slight improvement in $\mathrm{pH}$ values. This difference is due to the settlement of adhesive phase layers. However, when stirred, the phases become homogenized and

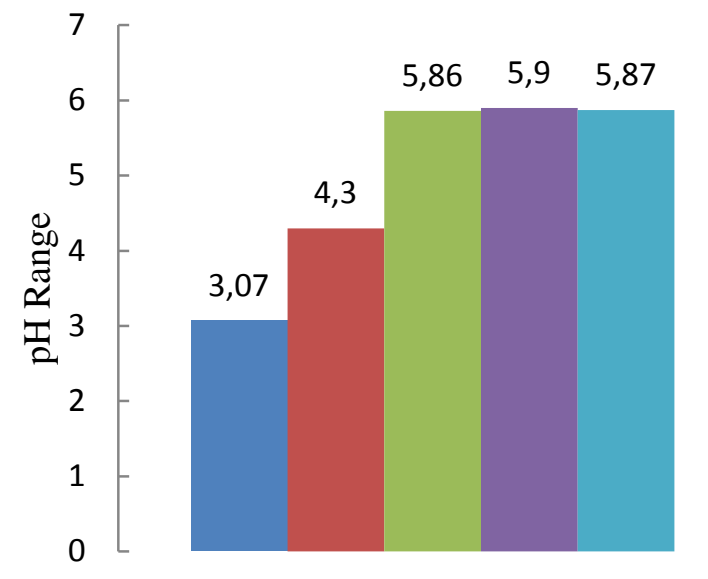

produced the corresponding value of the sample. Figure 6 presents the experimental results data for runs 5 . The samples $\mathrm{pH}$ was determine before and after stirring. Run $5 \mathrm{~A} \& \mathrm{~B}$ values were $<4$, while C, D \& E were $>4$ as shown.

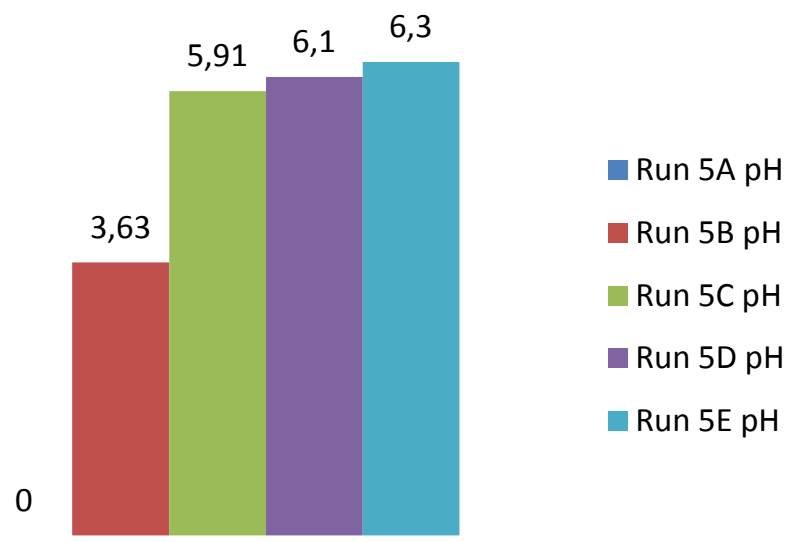

Figure 6 - Run $5 \mathrm{pH}$ before and after Stirring

Run 5A \& B even after stirring could not improve the $\mathrm{pH}$ values, these high acid values shows that the adhesive produced from this run is not suitable for application in composite materials as high acid values will weakens the strength of the substrate. Runs 5 (C-E) show favorable $\mathrm{pH}$ value which falls within the reported values of UF resin used for particleboard production.

The produced adhesives were characterized for $\%$ M. C. as presented in Figures 7-9.

Figure 7 presents the \% M. C. of produced adhesive for Run 1 (A-E). Run $1 \mathrm{~B}$ has the lowest \% M. C. of $5.93 \%$ as compared to D (11.01\%), C (15.18\%), A (17.46\%) and E (40.47\%). This low moisture suggests that the model could be used as binders in formulation of composite materials production as high moisture degrade the quality of the adhesive rapidly. Figure 8.0 presents the $\%$ M. C. of Run 4 (A, B, C, D \% E) of produced adhesives. Out of the 5 samples, Run $4 \mathrm{D}$ had $8.76 \%$ being the least \% M.C. as compared to B $(10.74 \%), \quad \mathrm{C}(11.54 \%), \mathrm{E}(13.17 \%)$ and $\mathrm{A}$ (13.57\%).

This revealed that Run 4D could serve as binder in composite material such as particleboard production as it has met the required minimum $\%$ M. C. of adhesives used as reported [19, 27, 32, 33, 37]. 


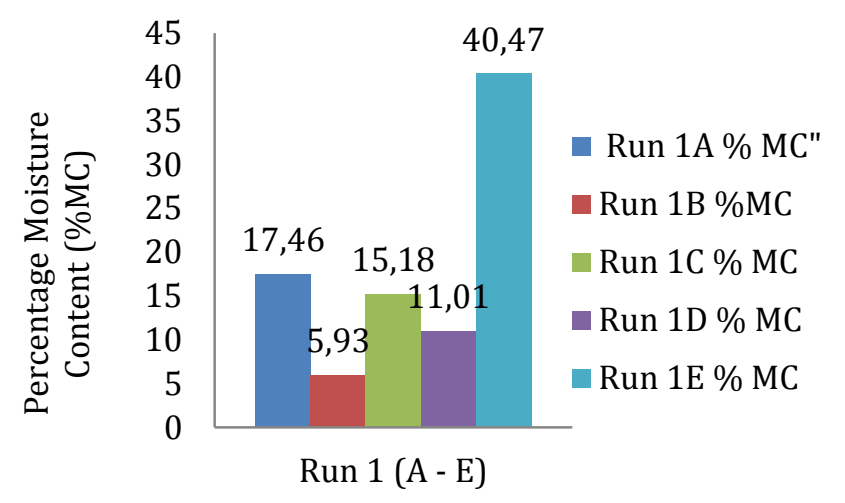

Figure 7 - Run $1 \%$ M. C.

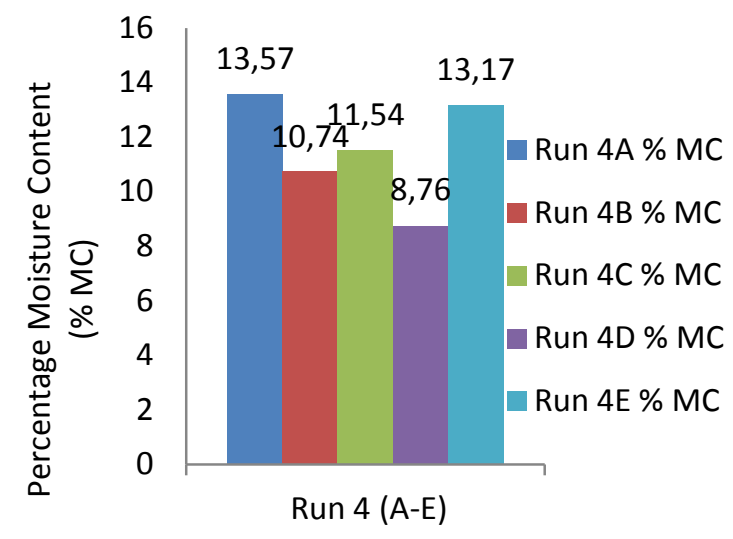

Figure 8 - Run $4 \%$ M. C.

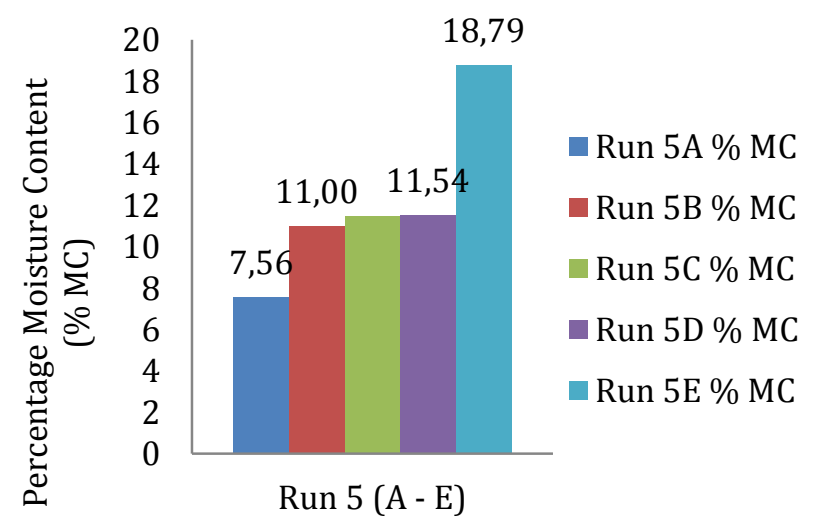

Figure 9 - Run $5 \%$ M. C.

Figure 9 presents the \% M. C. of Run 5 (A, B, C, D $\&$ E) of produced adhesives. Out of the 5 samples, Run 5A were found to be least with $7.57 \%$ as compared to B (11\%), C (11.45\%), D (11.54\%) and $\mathrm{E}(17.85 \%)$ respectively. This shows that adhesive with low \% M. C. has better property of bonding to substrate and might not degrade rapidly. And of all the samples, Run 1B was the least and best fit based on the urea formaldehyde adhesive used in particleboard as reported is Run $1 \mathrm{~B}<5 \mathrm{~A}<4$ D.

Figures 10-11 presents the \%TS contents of the produced adhesive for different experimental runs.

Figure 10 presents percentage solid contents for run 1 (A, B, C, D \& E). The following data were obtained from the experimental runs. A $67.01 \%$, B $67.19 \%$, C $58.36 \%$, D $61.39 \%$ and E $48.41 \%$, these implies data, Run $1 \mathrm{~B}$ exhibits the highest $\%$ TS of $67.19 \%$ which depicts the solid content of urea formaldehyde used for particleboard reported by [24] which had \%TS $>65 \%$ for nonwater soluble adhesive. While other runs falls below $65 \%$ is not within the expected range of adhesive solid content.

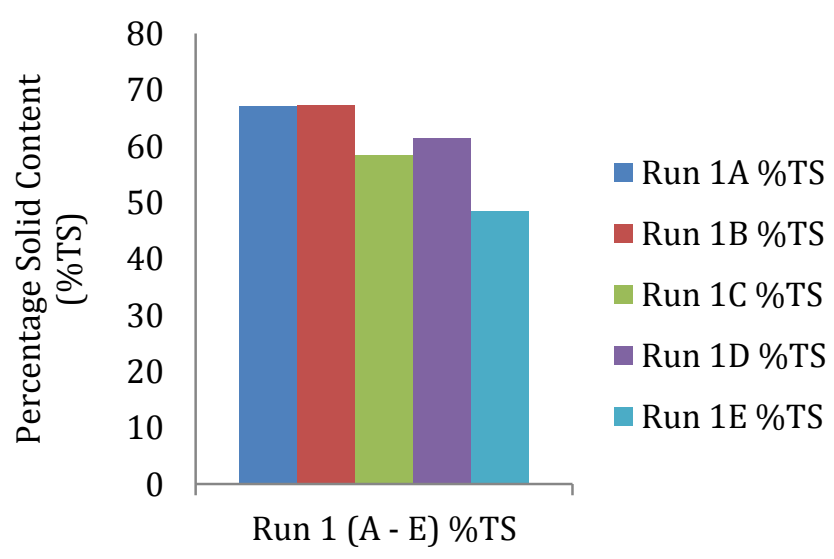

Figure 10 - Run $1 \%$ Solid Content

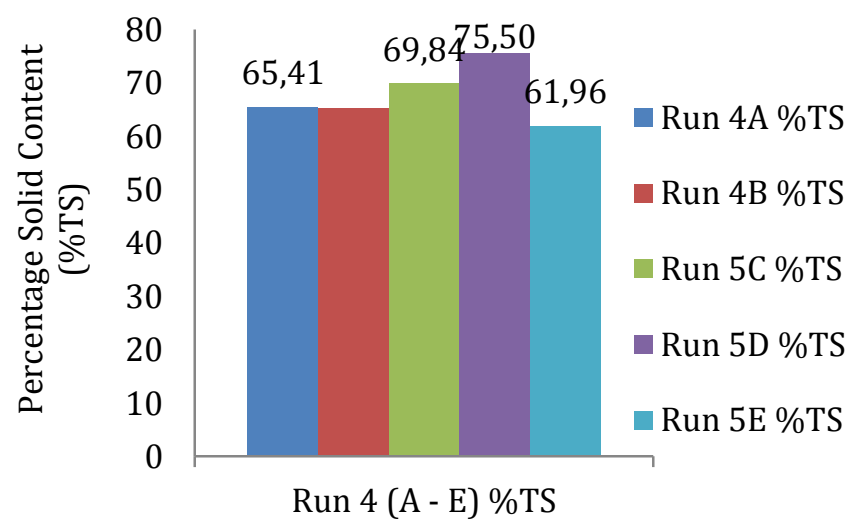

Figure 11 - Run 4 \% Solid Content

Figure 11 presents the \%TS for run 4 (A, B, C, D \& E). The results shows that A $65.41 \%$, B $65.15 \%$, C $69.84 \%$, D $75.50 \%$ and E $61.96 \%$. from these analysis only run $4 \mathrm{E}$ which has $61.96 \%$ TS fall below the TS of adhesive reported used in parti- 
cleboard production, whereas runs 4 (A -D) are above $65 \%$. This implies that adhesives from runs 4 (A-D) could be used for composite material production if other quality parameters are met as reported [24, 27, 28].

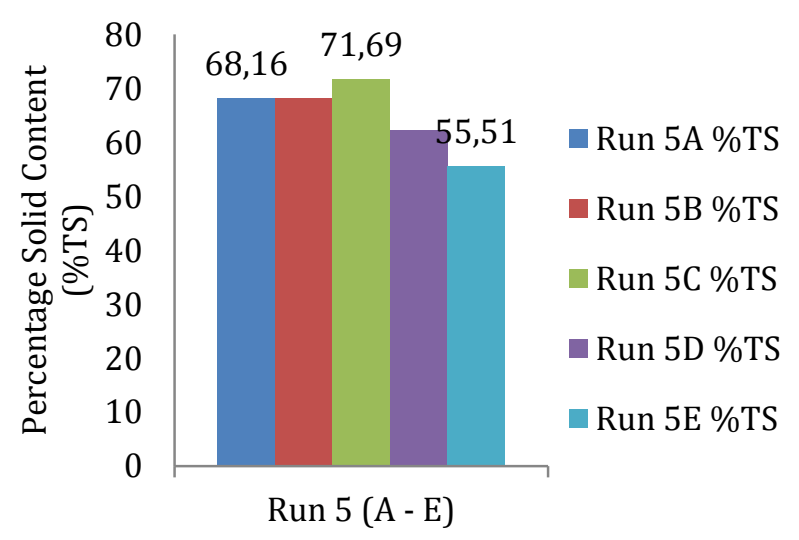

Figure 12 - Run $5 \%$ Solid Content

Figure 12 presents the \% TS for run 5 (A, B, C, D \& E). The results shows that A $68.16 \%$, B $68.22 \%$, C $71.69 \%$, D $62.15 \%$ and E $55.51 \%$. From these analysis Runs 5 (D \&E) falls below $65 \%$ and Runs $5(\mathrm{~A}-\mathrm{C}$ ) are within the range $>65 \%$ for nonwater soluble adhesive. Thus, the produced adhesives with \%TS above the urea formaldehyde adhesive used in particleboard and other panels could be used in the production of composites materials such as particleboard [24, 27, 28].

\section{CONCLUSION}

Adhesive was formulated from polystyrene and tackifyer, using additives as stabilizer. The process revealed that, polystyrene to tackifyer ratios of 0.5625 to 0.4375 was the adequate proportions for resin formulation; while additives with ratios of plasticizer $(0.19)$ and antioxidant $(0.01)$ blended with resins $(0.80)$ produced the best fitted adhesive among others. Run $1 \mathrm{~B}$ with viscosity of $3006 \mathrm{cPs}$ was best fitted based on the $\mathrm{R}^{2}$ and ANOVA from the design expert. The corresponding $\mathrm{pH}$ of 4.5 , percentage total solid content of $67.19 \%$ and percentage moisture content of $5.93 \%$ were obtained. The design expert modeling suggested that; Run $1 \mathrm{~B}$ could be used to navigate the model as it has met the criterion for adhesive used in panels. Therefore; the produced adhesive could be used for particleboard production.

\section{ACKNOWLEDGEMENTS}

The authors gratefully thank Abubakar Tafawa Balewa University for allowing this work to be carried out in Civil and water, Petroleum Engineering and Chemistry Laboratories at no cost.

\section{REFERENCES}

1. Sridhar, M. K. C., \& Hammed, T. B. (2014). Turning Waste to Wealth in Nigeria: An Overview. Journal of Human Ecology, 46(2), 195-203. doi: 10.1080/09709274.2014.11906720

2. Ogbonna, D. N., Ekweozor, I. K. E., \& Igwe, F. U. (2002). Waste Management: A Tool for Environmental Protection in Nigeria. AMBIO: A Journal of the Human Environment, 31(1), 55-57. doi: 10.1579/0044-7447-31.1.55

3. Ademović, Z., Suljagić, J., \& Zulić, J. (2017). Influence of Physical Properties on Thermal Conductivity of Polystyrene Insulation Materials. Contemporary Materials, 8(1), 42-47.

4. Gaur, U., \& Wunderlich, B. (1982). Heat Capacity and Other Thermodynamic Properties of Linear Macromolecules. V. Polystyrene. Journal of Physical and Chemical Reference Data, 11(2), 313325. doi: $10.1063 / 1.555663$

5. Deveci, H., Ahmetli, G., Ersoz, M., \& Kurbanli, R. (2012). Modified polystyrenes: Corrosion, physicomechanical and thermal properties evaluation. Progress in Organic Coatings, 73(1), 1-7. doi: 10.1016/j.porgcoat.2011.08.011

6. Rouabah, F., Dadache, D., \& Haddaoui, N. (2012). Thermophysical and Mechanical Properties of Polystyrene: Influence of Free Quenching. ISRN Polymer Science, 2012, 1-8. doi:

$10.5402 / 2012 / 161364$ 
7. García, M. T., Gracia, I., Duque, G., Lucas, A. de, \& Rodríguez, J. F. (2009). Study of the solubility and stability of polystyrene wastes in a dissolution recycling process. Waste Management, 29(6), 1814-1818. doi: 10.1016/j.wasman.2009.01.001

8. Chau, V. V., Bunge, F., Duffy, J., \& Hood, L. (2011). Advances in Thermal Insulation of Extruded Polystyrene Foams. Cellular Polymers, 30(3), 137-155.

9. Yang, Y., Yang, J., Wu, W.-M., Zhao, J., Song, Y., Gao, L., ... Jiang, L. (2015). Biodegradation and Mineralization of Polystyrene by Plastic-Eating Mealworms: Part 1. Chemical and Physical Characterization and Isotopic Tests. Environmental Science \& Technology, 49(20), 12080-12086. doi: 10.1021/acs.est.5b02661

10. Sekharan, R. V., Abraham, B. T., \& Thachil, E. T. (2012). Utilization of waste expanded polystyrene: Blends with silica-filled natural rubber. Materials \& Design, 40, 221-228. doi: 10.1016/j.matdes.2012.03.042

11. Patten, J., \& Meade, D. (2012, December 31). Green Manufacturing Initiative. Retrieved from https://www.osti.gov/servlets/purl/1072353/

12. Adjova, E., Olodo, E., \& Doko, V. (2018). Study of the implementation of waste wood, plastics and polystyrene from industries for various applications in the building industry. Retrieved from http://challengest.scienceafrique.fr/results_phase1.php

13. Osemeahon, S. A., Barminas, J. T., \& Jang, A. L. (2013). Development of Waste Polystyrene as a binder for emulsion paint formulation II: Effect of different types of Solvent. Journal of Environmental Science, Toxicology and Food Technology, 5(4), 1-7.

14. Curiac, A. S., Petre, A., Stoica, A. G., \& Sandu, S. A. (2017). Preparation of adhesives from the expandable polystyrene waste. Journal of Young Scientist, 5, 21-25.

15. Silva, F. B. M., Vianna, R. F., \& Neubert, E. I. (2014). Study of Adhesion Properties of Natural Rubber Based Pressure Sensitive Adhesive with Variation of Tackifier Resin and Plasticizers Agents. Retrieved from https://pdfs.semanticscholar.org/78ed/e59a22f0762a6a82d25bafcbdab84711b1a0.pdf

16. Landrock, A., \& Ebnesajjad, S. (2015). Adhesives Technology Handbook (3rd ed.). Amsterdam: Elsevier.

17. Dinwoodie, J. M. (1977). Causes of Deterioration of UF Chipboard under Cyclic Humidity Conditions - I. Performance of UF Adhesive Films. Holzforschung, 31(2), 50-55. doi:

10.1515/hfsg.1977.31.2.50

18. Abdulkareen, S. A., \& Adeniyi, A. G. (2017). Production of Particleboard Using Polystyrene and Bamboo Wastes. Nigerian Journal of Technology, 36(3), 788-793.

19. Zhu, L. B., Han, B., Gu, J. Y., Zhang, Y. H., Tan, H. Y., \& Zuo, Y. F. (2010). Preparation of WaterResistance Plywood with UF Resin Modified by Emulsifiable Polyisocyanate. Applied Mechanics and Materials, 26-28, 1056-1060. doi: 10.4028/www.scientific.net/amm.26-28.1056

20. Asha, A. (2017). Fabrication of Particle Boards from Rice Husk. International Journal of Modern Engineering Research, 7(5), 30-38.

21. Sekine, Y. (2001). Removal of formaldehyde from indoor air by passive type air-cleaning materials. Atmospheric Environment, 35(11), 2001-2007. doi: 10.1016/s1352-2310(00)00465-9

22. Salman, M., Athar, M., Shafique, U., Rehman, R., Ameer, S., Ali, S., \& Azeem, M., (2011). Removal of Formaldehyde from Aqueous Solution by Adsorption on Kaolin and Bentonite: A Comparative Study. Turkish Journal of Engineering and Environmental Sciences, 36(1), 263-270.

23. Xing, C., Zhang, S. Y., Deng, J., \& Wang, S. (2006). Urea-formaldehyde-resin gel time as affected by the $\mathrm{pH}$ value, solid content, and catalyst. Journal of Applied Polymer Science, 103(1), 1556-1569.

24. Derikvand, M., \& Pangh, H. (2015). A Modified Method for Shear Strength Measurement of Adhesive Bonds in Solid Wood. BioResources, 11(1). doi: 10.15376/biores.11.1.354-364 
25. Arendt, W. D., McBride, E., \& Conner, M. M. (2014). Use of Dibenzoate Plasticizers in Pressure Sensitive Adhesives. Retrieved from https://www.pstc.org/i4a/pages/index.cfm?pageID=4491

26. Melo, R. R. de, Stangerlin, D. M., Santana, R. R. C., \& Pedrosa, T. D. (2014). Physical and mechanical properties of particleboard manufactured from wood, bamboo and rice husk. Materials Research, 17(3), 682-686. doi: 10.1590/s1516-14392014005000052

27. Elbadawi, M., Osman, Z., Paridah, T., Nasroun, T., \& Kantiner, W. (2015). Mechanical and Physical Properties of Particleboards made from Ailanthus Wood and UF resin Fortified by Acacias Tannins Blend. Journal of Materials and Environmental Sciences, 6(4), 1016-1021.

28. Schmitz. Jr, J. F. (2009). Enzyme Modified Soy Flour Adhesive (Doctoral Dissertation), Iowa State University. N. d.

29. Šedivka, P., Bomba, J., Böhm, M., \& Boška, P. (2015). Influence of Temperature on the Strength of Bonded Joints. BioResources, 10(3). doi: 10.15376/biores.10.3.3999-4010

30. Bomba, J., Cvach, J., Šedivka, P., \& Kvietková, M. (2013). Strength Increase Pattern in Joints Bonded with PVAc Adhesives. BioResources, 9(1). doi: 10.15376/biores.9.1.1027-1037

31. Bomba, J., Šedivka, P., Böhm, M., \& Devera, M. (2014). Influence of Moisture Content on the Bond Strength and Water Resistance of Bonded Wood Joints. BioResources, 9(3). doi: 10.15376/biores.9.3.5208-5218

32. Pan, Z., Cathcart, A., \& Wang, D. (2005). Thermal and chemical treatments to improve adhesive property of rice bran. Industrial Crops and Products, 22(3), 233-240. doi: 10.1016/j.indcrop.2005.01.003

33. Pan, Z., Zheng, Y., Zhang, R., \& Jenkins, B. M. (2007). Physical properties of thin particleboard made from saline eucalyptus. Industrial Crops and Products, 26(2), 185-194. doi: 10.1016/j.indcrop.2007.03.006

34. Sulaiman, N. S., Hashim, R., Amini, M. H. M., Sulaiman, O., \& Hiziroglu, S. (2013). Evaluation of the Properties of Particleboard Made Using Oil Palm Starch Modified with Epichlorohydrin. BioResources, 8(1), 283-301.

35. Singh, C. P., Gupta, S., Sharma, C. M., \& Kishan Kumar, V. S. (2013). Effect of Solid Content of Adhesive on the Compression Strength of Finger Jointed Sections. Indian Forester, 139(7), 590593.

36. Strickland, B. (2013, April 11). Introduction to Adhesives. Retrieved from https://healthdocbox.com/87083882-Cholesterol/Introduction-to-adhesives.html

37. Kurt, R., \& Cil, M. (2012). Effects of press pressures on glue line thickness and properties of laminated veneer lumber glued with phenol formaldehyde adhesive. BioResources, 7(4). doi: 10.15376/biores.7.4.5346-5354 